\title{
Clinical and Histopathological Evaluation of Terbinafine Treatment in Cats Experimentally Infected with Microsporum canis
}

\author{
T. KOTNIK ${ }^{1}$, M. ČERNE ${ }^{2}$ \\ ${ }^{1}$ Small Animal Clinic, Veterinary Faculty, University of Ljubljana, Slovenia \\ ${ }^{2}$ Institute of Pathology, Forensic and Administrative Veterinary Medicine, Veterinary Faculty, \\ University of Ljubljana, Slovenia \\ Received October 25, 2005 \\ Accepted June 30, 2006
}

\begin{abstract}
T. Kotnik, M. Černe: Clinical and Histopathological Evaluation of Terbinafine Treatment in Cats Experimentally Infected with Microsporum canis. Acta Vet. Brno 2006, 75: 541-547.

The efficacy of terbinafine hydrochloride (Lamisil ${ }^{\circledR}$, Novartis) in the treatment of $27 \mathrm{M}$. canisinfected cats was followed. Treatment was started on the $17^{\text {th }}$ day post inoculation (p.i.), when successful experimental infection was proved. Nine cats were treated with low-dose terbinafine 10$20 \mathrm{mg} / \mathrm{kg}$ QD (LD group), nine cats were treated with high-dose terbinafine 30- $40 \mathrm{mg} / \mathrm{kg}$ QD (HD group) and nine were left untreated as a control group (C group). The efficacy of the treatment was evaluated using Wood's lamp examination, fungal culture and histopathology. All cats were positive 14 days p.i. Sixty days p.i. 8 cats from the LD group, 9 from the $\mathrm{C}$ group and 2 cats from the HD group had fungi in the tissue. Ninety days p.i. the HD group was free of fungi in the skin and other tests became negative on the $120^{\text {th }}$ day p.i. Statistically significant differences were found between the HD group and both of the other groups $(p<0.005)$ on $60^{\text {th }}$ and the $90^{\text {th }}$ day p.i. Experimental infection with $M$. canis yielded an inflammatory reaction of a mononuclear and neutrophil type in the cat skin. Hyperplastic interstitial dermatitis was a predominant tissue reaction although other types were also present during the study.
\end{abstract}

Dermatophytes, small animals, antifungals, histopathology

Microsporum canis is a fungus, most commonly recognized as the cause of dermatophytosis in cats ( S cott et al. 2001). Terbinafine hydrochloride is newly synthesised allylamine that has been successfully used for the treatment of mycoses in people (Breckenridge 1992; Goodfield 1992; Haroon et al. 1992). Terbinafine hydrochloride inhibits biosynthesis of ergosterol in the cell of the fungus by selective and specific binding to the enzyme squalen epoxidase. Squalen epoxidase promotes the synthesis of ergosterol in fungi, as well as the synthesis of cholesterol in mammals. Mammalian squalen epoxidase is much less sensitive to inhibition by terbinafine than the fungal enzyme (Ryder and Dupont 1985). Due to the inhibition of squalen epoxidase the lack of ergosterol and the accumulation of squalen occur in the fungus cell. That leads to the death of the cell. The accumulation of squalen seems to be the main mechanism of fungicidal action of terbinafine and permits shorter therapy courses in people (Goodfield 1992). Terbinafine has been used in animals mostly during pre-clinical studies (Mieth and Petranyi 1989). Only few reports were found of the drug currently being used in cats (Mala 1995; Mancianti et al. 1999; Castanon-Olivares et al. 2001). The purpose of our study was to follow the efficacy of terbinafine hydrochloride (Lamisil ${ }^{\circledR}$, Novartis) in the treatment of cats experimentally infected with $M$. canis. Clinical observation, Wood's lamp examination, fungal culture and histopathology were used for monitoring the effects of the treatment. Histopathology can be a useful diagnostic method in dermatophytoses, when it is necessary to distinguish between infection and skin carriage of a fungus ( $S$ cott et al. 1995). Since $M$. canis was inoculated experimentally into the skin, histopathology was used as 
a proof of successful experimental infection. By histopathology also the final eradication of fungi from the tissue at the site of inoculation was proved. It was used also for observing the tissue response during the treatment.

\section{Animals \\ Materials and Methods}

Three groups of nine young domestic cats of both sexes were included in the study. At the beginning of the experiment, their age ranged between 1.5 and 4.5 months. Cats were dermatophyte-naive, feline immunodeficiency virus (FIV) and feline leukaemia virus (FeLV) free. The study was performed in accordance with guidelines for the use of experimental animals. Authorisation from the Ethical Committee on animal experimentation of the Veterinary Administration of the Republic of Slovenia was obtained prior to the start of the study.

\section{Preparation of infectious material}

Infectious material was prepared using a slightly modified method by Sparkes et al. (1995). We used M. canis strain No. 1032/97 isolated from a hair sample of a naturally infected cat, that was positive under the Wood's lamp illumination. The hair sample was cultured on Sabouraud's dextrose agar (Sabouraud agar, bioMérieux, no. 51077, Marcy L'Etoile, France, 1997) with penicillin (500 mg/l) and streptomycin (500 mg/l) and Sabouraud's dextrose agar (Sabouraud Chloramphenicol Actidione agar, bioMérieux, no. 51079, Marcy L'Etoile, France, 1997) with the addition of chloramphenicol $(500 \mathrm{mg} / \mathrm{l})$ and actidion $(500 \mathrm{mg} / \mathrm{l})$. Primary cultures 14 days of age were subcultured. Plates with 20 days old subculture were filled with $10 \mathrm{ml}$ of distilled water and harvested using a sterile cotton swab. A suspension contained about $7 \times 10^{8} \mathrm{CFU}$ (colony forming units, spores)/l. It was stored at $+4{ }^{\circ} \mathrm{C}$ and used for experimental infection in three consecutive days.

\section{Experimental infection}

Cats were tranquilised using medetomidine (Domitor ${ }^{\circledR}$, Orion corp. Farmos, Finland) at the dose of $0.1 \mathrm{ml} / \mathrm{kg}$ i.m. Hair was clipped on the left side of the thorax to a length of $1-2 \mathrm{~mm}$ in the $20 \mathrm{~cm}^{2}$ field, using electric scissors. The skin in this field was mildly scarified using a scalpel blade. An amount of $1.0 \mathrm{ml}$ of the contagious suspension was inoculated into the scarified skin using sterile cotton swabs. Elizabethan collars were used to prevent licking. The procedure was repeated for the next 2 days, with the exception of clipping and scarification. The Elizabethan collars were kept in place for 14 days after the inoculation. The successful infection was confirmed by Wood's lamp examination, fungal culture and histopathology.

\section{Treatment with terbinafine}

Treatment was started on the $17^{\text {th }}$ day post inoculation (p.i.), when successful experimental infection was proved by Wood's lamp examination, histopathology and fungal culture results. Cats were randomised in three groups of nine before the treatment. Terbinafine hydrochloride tablets (Novartis, 112 MFD 1097) were used. Tablets were administered orally to each cat separately. Cats in the first, low-dose group (LD group), were treated with $10-20 \mathrm{mg} / \mathrm{kg}$ QD, cats in the high-dose group (HD group) were treated with $30-40 \mathrm{mg} / \mathrm{kg}$ QD and cats in the third, control group (C group) were left untreated. Doses were adjusted weekly, according to the increasing weight of growing cats. The drug was administered until fungal cultures of all cats from both treated groups became negative (HD group was treated until $120^{\text {th }}$ day p.i. and LD group was treated till $182^{\text {th }}$ day p.i.).

Clinical observation and collection of the material

Wood's lamp examination and evaluation of clinical symptoms were performed on a regular weekly basis. Hair was collected using the MacKenzie method every 14 days and stored at room temperature for fungal culture. At the end of sampling, fungal culture was performed for all three groups of cats on days $0,14,90,120,140,154,168$ and $182 \mathrm{p}$.i. At the site of inoculation of the infectious material skin samples were taken using $6 \mathrm{~mm}$ punch biopsy blades (Kruuse) on the $7^{\text {th }}, 14^{\text {th }}, 30^{\text {th }}, 60^{\text {th }}, 90^{\text {th }}$ and $120^{\text {th }}$ day p.i. Each time one skin sample was taken from the infected site. As the hair grew during the study, it was clipped to a length of $1 \mathrm{~mm}$ when needed. All nine cats in the control group also had normal skin taken from the opposite site of the thorax. Cats were tranquillised using medetomidine (Domitor ${ }^{\circledR}$, Orion Corp. Farmos, Finland) at a dose of $0.1 \mathrm{ml} / \mathrm{kg}$ i.m. Additionally $2 \%$ Xylocaine (Astra ${ }^{\circledR}$, Soedertaelje, Sweden) was used for local anaesthesia. When the procedure was expected to take a longer time, a combination of medetomidine at a dose of $0.1 \mathrm{ml} / \mathrm{kg}$ and ketamine (Ketamin $10 \%$ R, Veyx-Pharma GmbH, Schwarzenborn, Germany) at a dose of $3 \mathrm{mg} / \mathrm{kg}$ i.m. was used. In this case local anaesthetic was not used.

\section{Sample treatment and evaluation}

Biopsy specimens were fixed in $10 \%$ neutral phosphate buffered formalin. A standard method was used for paraffin embedding. Each specimen was cut 3 times at three different levels to $6 \mu \mathrm{m}$ slices. Slices were haematoxylin-eosin (H\&E) stained and Periodic acid Schiff (PAS) treated. H\&E slices were evaluated for histopathological changes in skin tissue and the presence of the inflammatory cells at the site of experimental infection. Five specimens from each group of cats were randomly chosen for each sampling period. Using $40 \times$ or $100 \times$ magnification, a significant slice and a significant site in the slice were chosen.

The histopathological patterns were classified into 4 groups, according to literature (Scott et al. 1995): perifolliculitis, folliculitis and furunculosis, hyperplastic or spongiotic superficial perivascular or interstitial dermatitis, intraepidermal pustular dermatitis, nodular diffuse granulomatous to pyogranulomatous panniculitis and dermatitis. 
Statistical methods

Quantitative results were evaluated by Student's $t$-test and the qualitative data by $\chi^{2}$ test, both using Statistical Analysis Software (SAS Institute, Carry, NY, USA).

\section{Results}

According to fungal culture results all cats were negative on day 0 (the day of inoculation). Experimental infection was successful in all cats and proved by Wood's lamp illumination of hairs, fungal culture and histopathology on day 14 p.i.

The condition of cats during treatment was generally good. Sometimes soft stool was noticed and two cats (one from HD group and one from LD group) vomited 10 minutes after administration of the drug. The problem was solved by feeding cats immediately after administration of the drug.

Table 1. Comparison of Wood's lamp illumination results and presence of fungi in the inoculated tissue

(PAS reaction), at different times p.i. in all three groups of cats

\begin{tabular}{|c|c|c|c|c|c|c|c|c|c|}
\hline \multirow{2}{*}{$\begin{array}{c}\text { Days } \\
\text { p.i. }\end{array}$} & \multicolumn{3}{|c|}{ Control $(\mathrm{n}=9)$} & \multicolumn{3}{c|}{ Low dose $(\mathrm{n}=9)$} & \multicolumn{3}{c|}{ High dose $(\mathrm{n}=9)$} \\
\cline { 2 - 10 } & $\begin{array}{c}\text { Wood's } \\
\text { lamp + }\end{array}$ & $\begin{array}{c}\text { Fungal } \\
\text { culture }\end{array}$ & $\begin{array}{c}\text { Fungi in } \\
\text { the tissue }\end{array}$ & $\begin{array}{c}\text { Wood's } \\
\text { lamp + }\end{array}$ & $\begin{array}{c}\text { Fungal } \\
\text { culture }\end{array}$ & $\begin{array}{c}\text { Fungi in } \\
\text { the tissue }\end{array}$ & $\begin{array}{c}\text { Wood's } \\
\text { lamp + }\end{array}$ & $\begin{array}{c}\text { Fungal } \\
\text { culture }\end{array}$ & $\begin{array}{c}\text { Fungi in } \\
\text { the tissue }\end{array}$ \\
\hline 0 & 0 & 0 & 0 & 0 & 0 & 0 & 0 & 0 & 0 \\
\hline 14 & 9 & 9 & 9 & 9 & 9 & 9 & 9 & 9 & 9 \\
\hline 60 & 9 & 9 & 9 & 9 & 8 & 8 & 7 & 3 & 2 \\
\hline 90 & 9 & 9 & 8 & 8 & 7 & 8 & 3 & 2 & 0 \\
\hline 120 & 6 & 9 & 1 & 7 & 7 & 4 & 0 & 0 & 0 \\
\hline
\end{tabular}

Legend: Table shows the number of cats with positive results of Wood's lamp illumination at the site of inoculation, number of cats with positive fungal culture, and number of cats with present fungi in the tissue at different times post inoculation (p.i.). Control group: non-treated cats, Low dose group: cats treated with $10-20 \mathrm{mg} / \mathrm{kg} \mathrm{QD}$, High-dose group: cats treated with $30-40 \mathrm{mg} / \mathrm{kg}$ QD.

Thirty days p.i. one cat from HD group was negative while fungi were still present in the tissues of all the other cats (Fig. 1). Sixty days p.i., 8 cats from LD group, 9 from $C$ group and only 2 cats from HD group had fungi in the tissue. Ninety days p.i. the number of positive cats reduced significantly. The HD group was completely free of fungi in tissue at that time. We found a statistically significant difference between HD group and both other groups $(p<0.005)$ on the $60^{\text {th }}$ and the $90^{\text {th }}$ day p.i. We followed fluorescence under Wood's lamp illumination at the site of inoculation of infectious material. Ninety days p.i. the number of positive cats in HD group dramatically lowered (6 cats negative). At this time there was only one cat from LD group negative. One hundred and twenty days p.i. all cats from HD group were negative. Still 6 cats from C group and 7 cats from LD group were positive at that time. In all groups we noticed satellite lesions during the study. In both treated groups the duration of the satellite lesions was short. The number of positive fungal cultures in the HD group lowered extremely on $60^{\text {th }}$ day and became completely negative on $120^{\text {th }}$ day p.i. There were still 7 positive fungal cultures in LD group on $120^{\text {th }}$ day p.i. Fungal cultures in control group on $120^{\text {th }}$ day were still $100 \%$ positive.

On day 0 (day of inoculation) all fungal culture results were negative. On $14^{\text {th }}$ day they were $100 \%$ positive. After day 90 p.i. the number of positive fungal culture results has become different among all three groups. The difference between HD group and both other groups was statistically significant. There was no statistically significant difference between LD group and control group.

The degree of inflammation was evaluated on H\&E tissue slices according to the presence of different cells in dermis. It was established by counting the cells at oil-magnification. Next cell types were counted: lymphocytes, plasma cells, macrophages, neutrophils and 
Fungal culture results

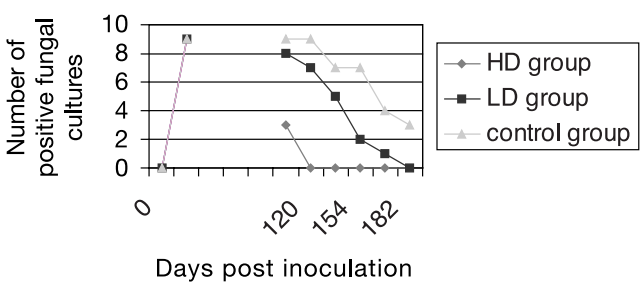

Fig. 1. Fungal culture results in all three groups of cats at different times post inoculation

eosinophils. In normal skin samples, taken from non-infected side of the thorax, 23 cells on average were counted. According to this result, all skin samples from the infected side, in which less than 30 cells would have been counted, were declared as normal. Mild inflammation was declared between 30 and 60 cells. More than 60 cells were present with moderate inflammation.

Number of inflammatory cells in dermis

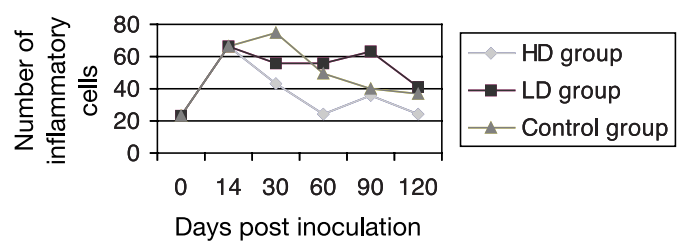

Fig. 2. The average numbers of inflammatory cells in dermis at the infected site in time in all three groups of cats

The number of inflammatory cells in dermis after the experimental infection increased markedly. On the $14^{\text {th }}$ day p.i. in all three groups of cats moderate inflammation was established (66.6 cells). In the control group the inflammation reached the peak on $30^{\text {th }}$ day p.i. After the $60^{\text {th }}$ day it became mild. In LD group mild inflammation was established between $30^{\text {th }}$ and $120^{\text {th }}$ day. In HD group only mild inflammation was detected on $30^{\text {th }}$ and $120^{\text {th }}$ day p.i. The number of cells on $120^{\text {th }}$ day in HD group was low (23.8) and comparable to normal skin (see Fig. 2).

The predominating histological pattern in all three groups of cats on the $30^{\text {th }}$ day was hyperplastic interstitial dermatitis (Plate II, Fig. 3). It remained predominating in the control and LD group on the $60^{\text {th }}, 90^{\text {th }}$ and $120^{\text {th }}$ day p.i., but not in the HD group. In the HD group it was replaced with normal skin. Folliculitis and furunculosis were recognised in all three groups until the $30^{\text {th }}$ day p.i., but after this it was not found any more in the HD group.

\section{Discussion}

This study showed that high-dose terbinafine (30-40 mg/kg QD) was more effective in treating experimental $M$. canis infection in young cats than low-dose terbinafine $(10-20 \mathrm{mg} / \mathrm{kg}$ QD). However, the completion of the treatment of the HD group took a long time. Since terbinafine acts fungicidally in people (R ashid 1996), we expected a shorter therapeutic course. The reason for the long course of treatment in our study might be a serious experimental infection, when a large number of spores were inoculated into scarified skin. Additional reason could be that metabolism of terbinafine in animal liver is 
more intensive that in the human liver, as Schuster and Ryder stated (1990). This might have prevented fungicidal effect of terbinafine in the present study and could be the reason, that LD group was not significantly different from the control group. Our results correlate to Mancianti's study (1999), done in 15 naturally M. canis-infected cats. The cats were treated with $30 \mathrm{mg} / \mathrm{kg}$ of terbinafine daily for 14 days and consecutive fungal cultures were performed at the end of the treatment, a month after and 3 months after the treatment was stopped. At the end of the treatment all 15 cats were still culture-positive. Thirty days later 11 of 15 cats were still positive and 3 months later one cat was still positive. Since the infection in our study was experimental, these two studies can be only partly compared. Yet, they both show a relatively long treatment course.

Two doses of the drug were used, because literature data on terbinafine use in cats at the time of the study were limited. To the authors' knowledge, two studies on the use of terbinafine in cats had been published at the time of our study. The first is Mala's (1995) pharmacokinetic study on terbinafine, where levels of terbinafine in the plasma were measured. These levels were optimal when the dose of $10 \mathrm{mg} / \mathrm{kg}$ QD was used. Unfortunately, they did not measure levels of terbinafine in the skin. We know that the levels of terbinafine in the human plasma may not be in positive correlation with the levels of terbinafine in the skin (Balfour and Faulds 1992), so we decided to test the suggested dose (10-20 mg/kg QD) and a higher dose (30-40 mg/kg QD) This decision was additionally supported by human experience from terbinafine treatment of human scalp infections. When scalp infections were caused by $M$. canis, longer therapy courses were observed compared to Trichophyton sp. scalp infections (Dragoš et al. 1995). Krafchik (1997) suggested that higher doses might shorten the therapy course. The second study on use of terbinafine in cats (Castanon-Olivares et al. 2001) was done on a group of asymptomatic carriers. The dose of $8.25 \mathrm{mg} / \mathrm{kg}$ QD was effective in elimination of the colonization, but might be insufficient to resolve an experimental infection, in our opinion. The already discussed study by Mancianti was published after we completed the study.

Young cats are most susceptible to a natural $M$. canis infection, and that was the reason this age-group was used in the study. A $M$. canis strain was used that gave a positive fluorescence under the Wood's lamp illumination which made it easier to follow the progress of the treatment. Wood's lamp examination was extremely helpful for the detection of satellite lesions. Satellite lesions appeared during the study in all three groups of cats, but disappeared quickly in both treated groups (LD g and HD g) but not in the control cats. This was ascribed to the effect of terbinafine.

Comparing Wood's lamp examination and fungal culture results we estimated that during later infection hairs can remain Wood's lamp positive, but fungal culture-negative. These results are comparable to Krafchik's (1997) statement that dead hyphae on hairs can still fluoresce under the Wood's lamp illumination.

Histological determination of fungal hyphae and spores with PAS reaction in our study showed as a less sensitive method. Compared to the large amount of material collected for fungal culture, with the histological procedure only a little amount of the tissue can be examined. This could be the reason for the great discrepancy between fungal culture results and histological results in the control group on the $120^{\text {th }}$ day p.i. Additional important fact in our study that significantly influenced these results, was appearance of satellite lesions. Satellite lesions appeared in the greatest number in the control group on the $60^{\text {th }}$ day p.i. ( 8 cats in group) and were present in 5 cats on the $120^{\text {th }}$ day. Biopsy was not taken from the satellite lesions.

Histopathological patterns in dermatophyte skin infections can be variable (Carlton and McGavin 1995) and that correlates also with our results. Interstitial dermatitis, perivascular dermatitis, interstitial hyperplasic dermatitis, perivascular hyperplastic 
dermatitis, folliculitis and furunculosis were found. During the early period p.i. (7-14 days), perivascular and interstitial dermatitis were predominant in the tissue. Hyperplastic interstitial dermatitis was the main finding later (Plate II, Fig. 3). No pseudomycetomas were found in the tissue and none were expected, because they are mainly found in immunocompromised people (V oisard et al. 1999) and Persian cats. In this study FIV- and FeLVfree domestic cats were used.

From all the facts discussed we can conclude that terbinafine can be used for the treatment of $M$. canis infection in cats. The use of a high dose (30-40 mg/kg QD) should be recommended.

\section{Histopatologické hodnocení léčby terbinafinem u koček pokusně infikovaných Microsporum canis}

Byla sledována účinnost hydrochloridu terbinafinu (Lamisil ${ }^{\mathrm{R}}$, Novartis) při léčbě 27 koček infikovaných $M$. canis. Léčba začala 17 . den po naočkování (p.i.) poté, co byla prokázána úšpěšná pokusná infekce. Devět koček bylo léčeno terbinafinem v nízké dávce $10-20 \mathrm{mg} / \mathrm{kg}$ QD (skupina ND), devět koček bylo léčeno terbinafinem ve vysoké dávce 30-40 mg/kg QD (skupina VD) a devět zůstalo bez ošetření jako kontrolní skupina (skupina K) . Účinnost léčby byla hodnocena vyšetřením pomocí Woodovy lampy, plísňové kultury a histopatologie. 14 dní p.i. byly všechny kočky pozitivní. 60 dní p.i. mělo 8 koček ze skupiny ND, 9 koček ze skupiny K a 2 kočky ze skupiny VD v tkáni plíseň. 90 dní p.i. byla skupina VD zbavena plísně v kủži a další testy byly negativní 120. den p.i. Statisticky významné rozdíly byly zjištěny mezi skupinou VD a druhými skupinami $(p<0,005)$ 60. a 90. den p.i. Pokusná infekce $M$. canis způsobila u kủže koček zánětlivou reakci mononukleárního a neutrofilního typu. Převládající tkáňovou reakcí byla hyperplastická intersticiální dermatitida, i když prítomné byly v průběhu studie i jiné typy.

\section{Acknowledgements}

This study was supported by grants from the Ministry of Science and Technology of Slovenia and from Novartis Sandoz pharma, Slovenia.

\section{References}

BALFOUR JA, FAULDS D 1992: Terbinafine: A review of its pharmacodynamic and pharmacokinetic properties, and therapeutic potential in superficial mycoses. Drugs 43 (2): 259-284

BRECKENRIDGE A 1992: Clinical significance of interactions with antifungal agents. Brit J Dermatol 126 (Suppl 39): 19-22

CARLTON WW, MCGAVIN MD 1995: Thomson's special veterinary pathology, $2^{\text {nd }}$ edn. Mosby-Year Book, Missouri, pp. 487-488

CASTANON-OLIVARES LR, MANZANO-GAYOSSO P, LOPEZ-MARTINEZ R et al. 2001: Effectiveness of terbinafine in the eradication of Microsporum canis from laboratory cats. Mycoses 44: 95-97

DRAGOŠ V, PODRUMAC B, KRALJ B, BARTENJEV I 1995: Efficacy of oral terbinafine treatment in tinea capitis in children caused by Microsporum canis. J Europ Acad Dermatol Venerol 5 (Suppl 1) : S171-S172

GOODFIELD MJD 1992: Short-duration therapy with terbinafine for dermatophyte onychomycosis: a multicentre trial. Brit J Dermatol 126 (Suppl 39): 33-35

HAROON TS, HUSSAIN I, MAHMOOD A et al. 1992: An open clinical pilot study of the efficacy and safety of oral terbinafine in dry non-inflammatory tinea capitis. Brit J Dermatol 126 (suppl 39): 47-50

KRAFCHIK B 1997: The clinical efficacy of terbinafine in the treatment of tinea capitis. Rev Contemp Pharmacoth 8: $313-324$

MALA G 1995: Zur Vertraglichkeit und Pharmakokinetik von Lamisil ${ }^{\circledR}$ bei der Katze. Der Medizinischen Universitätsklinik für Einhufer, Klientiere und Geflügel, Wien. Dissertation, 101 p.

MANCIANTI F, PEDONESE F, MILLANTA F, GUARNIERI L 1999: Efficacy of oral terbinafine in feline dermatophytosis due to Microsporum canis. J Felin Med Surg 1: 37-41

MIETH H, PETRANYI G 1989: Preclinical evaluation of terbinafine in vivo. Clin Exp Dermatol 14: 104-107

RASHID A 1996: New mechanisms of action with fungicidal antifungals. Brit J Dermatol 134: 1-6

RYDER NS, DUPONT MC 1985: Inhibition of squalene epoxidase by allylamine antimycotic compounds A comparative study of the fungal and mammalian enzymes. Biochem J 230: 765-770 
SCHUSTER I, RYDER NS 1990: Allylamines - Mode and selectivity of action compared to azole antifungals and biological fate in mammalian organisms. J Dermatol Treatm 1(suppl 2): 7-9

SCOTT DW, MILLER WH, GRIFFIN CE 1995: Small animal dermatology, $5^{\text {th }}$ Ed. W.B. Saunders, Philadelphia, $342 \mathrm{p}$.

SCOTT DW, MILLER WH, GRIFFIN CE 2001: Muller \& Kirk's Small animal dermatology, 6 ${ }^{\text {th }}$ Ed. W.B. Saunders, Philadelphia, $339 \mathrm{p}$.

SPARKES AH, STOKES CR, GRUFFYDD-JONES TJ 1995: Experimental M. canis infection in cats: correlation between immunological and clinical observations. J Med Vet Mycol 33: 177-184

VOISARD JJ, WEILL FX, BEYLOT-BARRY M, VERGIER B, DROMER C, BEYLOT C 1999: Dermatophytic granuloma caused by Microsporum canis in a heart-lung recipient. Dermatol 198: 317-319 
Plate II

Kotnik T. et al.: Clinical ... pp. 507-513

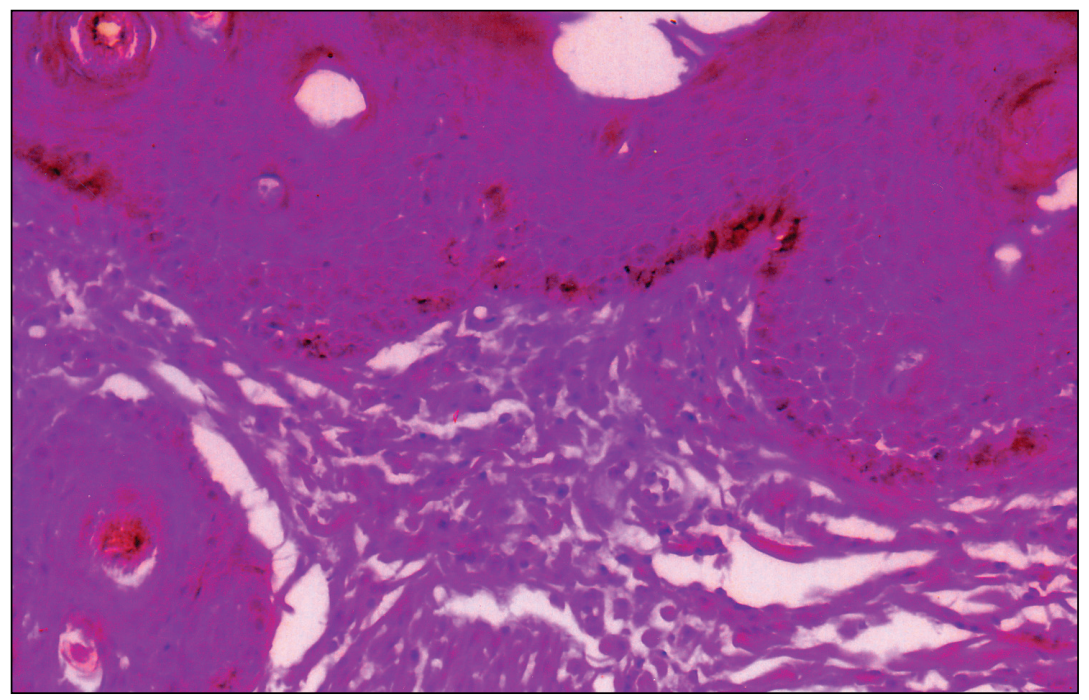

Fig. 3. Hyperplastic interstitial dermatitis in the cat skin. We can see inflammatory cells disseminated into the superficial dermis. Hyperplastic interstitial dermatitis was the predominating histopathological pattern found in our study. $\mathrm{H} \& \mathrm{E} \times 200$. 